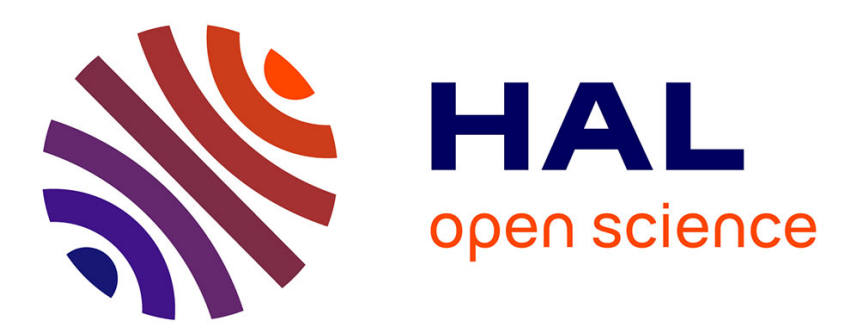

\title{
Spatial coexistence of American beech and sugar maple regeneration in post-harvest northern hardwood forests
}

\author{
Andrew S. Nelson, Robert G. Wagner
}

\section{To cite this version:}

Andrew S. Nelson, Robert G. Wagner. Spatial coexistence of American beech and sugar maple regeneration in post-harvest northern hardwood forests. Annals of Forest Science, 2014, 71 (7), pp.781-789. 10.1007/s13595-014-0376-2 . hal-01102875

\section{HAL Id: hal-01102875 \\ https://hal.science/hal-01102875}

Submitted on 13 Jan 2015

HAL is a multi-disciplinary open access archive for the deposit and dissemination of scientific research documents, whether they are published or not. The documents may come from teaching and research institutions in France or abroad, or from public or private research centers.
L'archive ouverte pluridisciplinaire $\mathbf{H A L}$, est destinée au dépôt et à la diffusion de documents scientifiques de niveau recherche, publiés ou non, émanant des établissements d'enseignement et de recherche français ou étrangers, des laboratoires publics ou privés. 


\title{
Spatial coexistence of American beech and sugar maple regeneration in post-harvest northern hardwood forests
}

\author{
Andrew S. Nelson • Robert G. Wagner
}

Received: 2 September 2013 / Accepted: 1 April 2014 / Published online: 1 May 2014

(C) INRA and Springer-Verlag France 2014

\begin{abstract}
- Context Fine scale regeneration patterns of coexistent species are influenced by regeneration mechanisms and microsite requirements. Spatial patterns may be either disjunct or overlapping, which will determine competitive effects and microsite dominance, and future forest composition.

- Aims Using American beech (Fagus grandifolia Ehrh.) and sugar maple (Acer saccharum Marshall) as an example, three hypotheses were tested: (1) random beech spatial patterns, (2) clumped spatial patterns of small sugar maple seedlings, and (3) disjunct beech and sugar maple patterns.

- Methods Individual stems were sampled in a contiguous grid of $1-\mathrm{m}^{2}$ quadrats across a $576-\mathrm{m}^{2}$ area at three sites. Densities were separated into three height classes $(\leq 30 \mathrm{~cm}$, $30-90 \mathrm{~cm}$, and $>90 \mathrm{~cm}, \leq 4 \mathrm{~cm}$ diameter at breast height). Spatial statistics and regression were used to analyze spatial patterns and correlations.

- Results Beech and seedling sugar maple patterns were patchy, rejecting the first and not rejecting the second hypotheses. Hypothesis three was rejected because patches of the two species overlapped with advance regeneration beech overtopping sugar maple.
\end{abstract}

\section{Handling Editor: Douglass Jacobs}

Contribution of the co-authors Andrew Nelson was responsible writing the manuscript, designing the study, collecting, and analyzing data. Robert Wagner was the primary supervisor and assisted in designing the study, interpreting the results, and preparing the manuscript.

A. S. Nelson • R. G. Wagner

School of Forest Resources, University of Maine, P.O. Box 5755,

Nutting Hall, Orono, ME, USA

Present Address:

A. S. Nelson $(\square)$

School of Forest Resources and Arkansas Forest Resources Center,

University of Arkansas at Monticello, P.O. Box 3468, Monticello,

AR 71656, USA

e-mail: nelsona@uamont.edu
- Conclusion Patchy patterns of advance regeneration beech and post-harvest sugar maple establishment suggest spatiotemporal niche partitioning. Beech had a competitive height advantage following harvest, but sugar maple still occurred in beech-free patches and beneath overtopping beech at a fine scale. Self-replacing beech patterns will ensure the species will continue dominance unless a selective chemical or manual treatment is applied that removes beech and releases sugar maple.

Keywords Niche partitioning - Spatial autocorrelation . Shelterwood harvest $\cdot$ Kriging $\cdot$ Patchy regeneration patterns

\section{Introduction}

Natural forest regeneration can be a stochastic process, influenced by the type of reproduction (sexual or asexual), dispersal characteristics (seed size, dispersal agents), and the availability of suitable microsites for germination and establishment (Kozlowski 2002). Once germinants become established, light and soil resources are required for survival. If regeneration is prolific, intra- and interspecific competition for available resources and microsite dominance soon occur. Therefore, patterns of individual survival and microsite dominance will also be influenced by species-specific traits (e.g., shade tolerance) through competitive interactions and responses to microsite characteristics (e.g., overstory light penetration) (Beatty 1984). This will influence whether spatial patterns of a particular species will be patchy or random in response to spatiotemporal microsite availability (Houle 1994; Messaoud and Houle 2006). For instance, the niche (sensu Grubb 1977) of some shade-tolerant species may include a stage as advance regeneration beneath partially closed canopies, where spatial patterns are determined by overstory canopy density and patterns of light extinction. 
Spatiotemporal regeneration niche partitioning, where resources are captured in different areas or at different times during development, can influence species coexistence (Grubb 1977). One example is regeneration dynamics in managed northern hardwood forests in north-central ME, USA. American beech (Fagus grandifolia Ehrh.) and sugar maple (Acer saccharum Marsh.) are adapted to partial overstory shading (Godman et al. 1990; Tubbs and Houston 1990), arising from small and moderate canopy gaps in these forests. Beech often develops as advance regeneration and can dominate the understory prior to overstory disturbance because of high shade tolerance and plastic growth responses to slight changes in understory light conditions (Poulson and Platt 1996; Tubbs and Houston 1990). Development as advance regeneration gives beech a competitive height advantage following overstory disturbance, possibly excluding other species (Bohn and Nyland 2003). Sugar maple can also establish as advance regeneration, but grows slower than beech under low-light conditions (Canham 1988). Comparatively, if sugar maple has a height advantage, it can outcompete beech in gaps (Canham 1990) and on sites with high soil calcium content (Juice et al. 2006). Sugar maple also produces many small seeds that may establish post-disturbance in gaps of suitable microsites, while the large size of beech seeds limits similar microsite capture.

There is interest in understanding the post-harvest regeneration patterns of beech and sugar maple in northern hardwood forests because beech has become an undesirable species for landowners. The species is affected by beech bark disease (Neonectria faginata (Lohman, Watson \& Ayers) Castl. \& Rossman and Neonectria ditissima (Tul. \& C. Tul.) Samuels $\&$ Rossman since the 1940s (Morin et al. 2007). Once a dominant species in the overstory, most beech trees decline and die, relegating beech to a perpetual understory and midstory species, rarely reaching $20 \mathrm{~cm}$ diameter at breast height (dbh) (Houston 1994). An understanding of beech and sugar maple spatial coexistence at fine scales can assist in the design of treatments to increase microsite availability for sugar maple. Therefore, the objectives of this study were to quantify the spatial patterns of and relationships between beech and sugar maple regeneration at the sub-stand level in post-harvest stands. In particular, three hypotheses were tested, including: (1) the spatial patterns of beech regeneration $(>6 \mathrm{~cm}$ tall but $<4 \mathrm{~cm} \mathrm{dbh}$ ) are random since preliminary observation suggested an even cover across the sites; (2) clumped small $(\leq 30 \mathrm{~cm}$ tall) sugar maple regeneration because of post-harvest establishment in areas absent of beech, while tall seedling sugar maple regeneration $(>30 \mathrm{~cm}$ tall, $<4 \mathrm{~cm}$ dbh) spatial patterns would be random because few microsites would be captured before harvest compared to beech; and (3) negative relationship between beech and sugar maple regeneration patterns because of competitive exclusion of sugar maple by beech.

\section{Methods}

\subsection{Study sites}

Three northern hardwood stands with beech-dominated understories were selected in north-central ME, USA that were managed by three different landowners. These stands were selected because beech regeneration dominated the sites after harvest, and sugar maple was in the overstory before and after harvest. Sites were located less than 20 miles of Millinocket, ME, USA. Site 1 (S1) was located at $45^{\circ} 49^{\prime} \mathrm{N}, 68^{\circ} 33^{\prime} \mathrm{W}$, Site 2 (S2) at $45^{\circ} 47^{\prime} \mathrm{N}, 68^{\circ} 42^{\prime} \mathrm{W}$, and Site 3 (S3) at $45^{\circ} 35^{\prime} \mathrm{N}, 68^{\circ}$ $36^{\prime} \mathrm{W}$, all $\sim 150 \mathrm{~m}$ above sea level in elevation. Mean monthly temperatures from the nearest weather station at Millinocket, ME, USA in January is $-10.0^{\circ} \mathrm{C}$, and $19.8^{\circ} \mathrm{C}$ in July, with an annual mean of $5.3^{\circ} \mathrm{C}$, and precipitation is evenly distributed throughout the year with an average of $1,058 \mathrm{~mm}$ per year. Soils at all sites are glacial till origin, Typic Haplorthods stony sandy-silty loams with slopes between 0 and $15 \%$. The three stands were located in a region first affected by beech bark disease between 1945 and 1950 (Morin et al. 2007). As of the early 2000s, the stands were in the "aftermath forest" disease progression stage, where trees rarely reach $20 \mathrm{~cm}$ dbh before dying, while seedlings and small saplings are prolific and rarely affected (Houston 1994).

Shelterwood establishment cuts were performed at all three sites between 2002 and 2004 with the objective of removing suppressed stems and enough overstory basal area to stimulate natural regeneration (landowner personal communication). In 2009, stump diameters were measured in all three sample areas. Stump diameter was used to predict dbh of the harvested trees using regression equations developed for Northeastern trees species by Wharton (1984). Predicted cut-tree dbh and measured dbh for residual trees were used to calculate residual and pre-harvest basal areas. All three sites had similar pre-harvest overstory basal area ranging from $29.9 \mathrm{~m}^{2} \mathrm{ha}^{-1}$ at $\mathrm{S} 2$ to $34.0 \mathrm{~m}^{2} \mathrm{ha}^{-1}$ at $\mathrm{S} 1$ (Table 1). Total basal area was reduced by $45.3,70.2$, and $39.5 \%$ at S1, S2, and S3, respectively. Sugar maple and beech were well represented in the overstory pre-harvest and post-harvest at all three sites. Other species were also present in the overstory, including red maple (Acer rubrum L.), striped maple (Acer pensylvanicum L.), yellow birch (Betula alleghaniensis Britton), white ash (Fraxinus americana L.), hophornbeam (Ostrya virginiana (Mill.) K. Koch), eastern hemlock (Tsuga canadensis (L.) Carriere), red spruce (Picea rubens Sarg.), and balsam fir (Abies balsamea (L.) Mill.).

\subsection{Study design}

Even though beech and sugar maple were dominant species in the post-harvest understories (Tables 2 and 3), red maple, striped maple, and yellow birch were also common at the 
Table 1 Pre-harvest and post-harvest overstory basal areas for all trees within the $576-\mathrm{m}^{2}$ sampling areas by species in $\mathrm{m}^{2}$ ha ${ }^{-1}$

\begin{tabular}{|c|c|c|c|c|c|c|}
\hline \multirow[b]{2}{*}{ Species } & \multicolumn{2}{|l|}{ Site 1} & \multicolumn{2}{|l|}{ Site 2} & \multicolumn{2}{|l|}{ Site 3} \\
\hline & Pre-harvest & Post-harvest & Pre-harvest & Post-harvest & Pre-harvest & Post-harvest \\
\hline Beech & 6.0 & 1.5 & 24.6 & 5.9 & 5.5 & 5.5 \\
\hline Sugar maple & 5.9 & 4.3 & 3.0 & 3.0 & 13.9 & 4.2 \\
\hline Red maple & 13.5 & 9.5 & - & - & - & - \\
\hline Striped maple & - & - & 0.1 & 0.1 & 0.4 & 0.4 \\
\hline Yellow birch & 0.2 & 0.2 & - & - & 4.3 & 1.7 \\
\hline White ash & - & - & - & - & 0.9 & 0.9 \\
\hline Hophornbeam & 0.4 & 0.4 & - & - & - & - \\
\hline Hemlock & - & - & - & - & 6.3 & 6.3 \\
\hline Red spruce & 2.4 & 1.6 & 2.3 & - & 1.8 & 1.4 \\
\hline Balsam fir & 2.3 & 1.1 & - & - & - & - \\
\hline Total & 34.0 & 18.6 & 29.9 & 8.9 & 33.7 & 20.4 \\
\hline
\end{tabular}

Pre-harvest basal areas were calculated using the cut-stump diameters and the stump-breast height regression equations developed in Wharton (1984)

three sites. At each site, a $24 \times 24-\mathrm{m}$ area between harvest trails was gridded into $1-\mathrm{m}^{2}$ sampling plots (576 contiguous plots). Individual stems by species were counted and stratified into three height classes: h1 $(6-30 \mathrm{~cm}), \mathrm{h} 2(31 \mathrm{~cm}-90 \mathrm{~cm})$, and h3 $(91 \mathrm{~cm}-<4 \mathrm{~cm} \mathrm{dbh})$ in each plot. Trees $\geq 4 \mathrm{~cm}$ dbh were few in the post-harvest stands since the treatments targeted midstory removal and were therefore excluded from analysis.

The age of beech and sugar maple regeneration and beech origin (seed vs. root sucker) were measured in each grid using four $50.27-\mathrm{m}^{2}$ plots. Stems sampled for age determination were selected by starting at the center of each plot and moving towards the plot edge at a random azimuth. Sampled stems were cut at the root collar until three stems per species and height class were obtained. Cut stems were kiln dried at $65^{\circ} \mathrm{C}$, sanded and aged $1 \mathrm{~cm}$ above the root collar using a hand lens. Beech origin was determined by removing the organic and upper mineral soil around individuals and observing the belowground rooting structure since beech root suckers are typically attached to shallow parent roots (Ward 1961). Sugar maple origin was not measured as part of this investigation, since the species is not known to root sucker and minimal stump sprouting was observed.

Table 2 Mean percent cover of the five most abundance hardwood species at three different sites

\begin{tabular}{lrrr}
\hline Species & Site 1 & Site 2 & Site 3 \\
\hline American beech & 26.9 & 39.3 & 12.6 \\
Sugar maple & 23.4 & 12.3 & 17.8 \\
Striped maple & 5.4 & 5.6 & 17.8 \\
Red maple & 6.5 & 1.5 & 4.9 \\
Yellow birch & 8.6 & 1.7 & 18.3 \\
\hline
\end{tabular}

Cover was estimated to the nearest $5 \%$ in each $1-\mathrm{m}^{2}$ sample plot

\subsection{Analytical approach}

\subsubsection{Regeneration spatial patterns}

Kriging was used to create smoothed surfaces of beech and sugar maple spatial patterns for all height classes and sites. Kriging is a geostatistical interpolation method commonly used to predict patterns at unknown locations, but can also provide an accurate representation of the spatial patterns of a completely sampled area. Variogram parameters for the kriged models were estimated in R (R Core Team 2013). The kriged surfaces were then created in ArcGIS using the geostatistical analyst extension and estimated variogram parameters.

Moran's I correlograms were used to test the hypotheses of beech and sugar maple spatial patterns. A significant Moran's I statistic (Bonferroni corrected $p<0.03$ ) at any distance indicates that spatial autocorrelation was detected in the data (Legendre and Fortin 1989). Moran's I statistics and significance tests were performed in $\mathrm{R}$ using the spdep package (Bivand 2013). The range of spatial autocorrelation, commonly interpreted as the average patch size (Legendre and Fortin 1989), was estimated as the distance of the last positive Moran's I value of the correlogram prior to non-significance at greater distances. For all correlograms, distance classes were binned into $1.6 \mathrm{~m}$ intervals based on preliminary analyses to maximize the number of plots in each distance class.

To test the hypothesis that beech and sugar maple regeneration densities were negatively related, linear mixed-effects models were fit using the nlme package in $\mathrm{R}$ (Pinheiro et al. 2013). A total of five models were selected. The models investigated the relationships between: (i) total beech and small (h1) sugar maple, (ii) large $(\mathrm{h} 2+\mathrm{h} 3)$ beech and small (h1) sugar maple, (iii) total beech and large $(\mathrm{h} 2+\mathrm{h} 3)$ sugar maple, (iv) large beech and large sugar maple, and (v) total 
beech and total sugar maple. Sugar maple density (stems $\mathrm{m}^{-2}$ ) was square root transformed to improve residuals prior to analysis. Study site was treated as a random effect in the models. Observations were not random since systematic grids were used for sampling. To account for the inherent spatial autocorrelation among observations, a spatial correlation term was included in the models accounting for spatial correlation in the residuals, blocked by site. Based on preliminary analysis, the spherical variogram was chosen to account for the isotropic spatial correlation in the models.

\section{Results}

\subsection{General understory conditions}

Across all three sites, beech regeneration was the most numerous in the $\mathrm{h} 2$ and $\mathrm{h} 3$ height classes, while sugar maple regeneration was more numerous in h1 ranging from $8.8 \times 10^{3}$ stems ha $^{-1}$ at S2 to $96.8 \times 10^{3}$ stems ha $^{-1}$ at S1 (Table 3). Beech regeneration at all three sites was predominantly seed origin, while root suckers accounted for only 11.2, 6.9, and $21.2 \%$ of beech regeneration at $\mathrm{S} 1, \mathrm{~S} 2$, and $\mathrm{S} 3$ respectively, thus unexpectedly making root suckering a minor contributor to beech regeneration in the understory (Table 4). Regeneration of $\mathrm{h} 3$ was the oldest at S2, averaging $9.9 \pm 3.1$ years for beech and $8.5 \pm 2.5$ years for sugar maple, indicating that $\mathrm{h} 3$ regeneration established prior to harvest. The average age of $\mathrm{h} 1$ beech and sugar maple were all less than 5 years indicating establishment after harvest.

\subsection{Regeneration spatial patterns}

The kriged surfaces (Figs. 1, 2, and 3) show variability in regeneration patterns between the two species, across sites and height classes. At S1, both species had patchy patterns, with the greatest beech densities in $\mathrm{h} 2$ and $\mathrm{h} 3$, while sugar maple patterns were dominated by h1. The kriged surfaces of S2 show a similar pattern of stratified patchy beech overtopping sugar maple, while at S3, sugar maple patches were more numerous than beech.
Beech and sugar maple both exhibited clumped spatial patterns for all three height classes. Pooled across height classes, the range of autocorrelation of beech was the greatest for S2 $(9.51 \pm 0.35 \mathrm{~m}), \mathrm{S} 3(6.28 \pm 0.28 \mathrm{~m})$, and S1 $(2.76 \pm$ $0.92 \mathrm{~m}$ ) (Table 5). Comparatively, the range of autocorrelation of sugar maple was similar among sites ranging from $7.51 \pm$ $0.12 \mathrm{~m}$ at S2 to $11.79 \pm 0.02 \mathrm{~m}$ at S3. The range of autocorrelation was not significantly different among height classes for both species $(p>0.05)$ (Table 6$)$. The range of autocorrelation for beech was the lowest for h1 $(3.52 \pm 0.90 \mathrm{~m})$ to $\mathrm{h} 3(8.08 \pm$ $0.51 \mathrm{~m}$ ), while for sugar maple, the smallest range of autocorrelation was for $\mathrm{h} 2(8.40 \pm 0.37 \mathrm{~m})$ and the largest for $\mathrm{h} 1$ $(10.67 \pm 0.18 \mathrm{~m})$.

\subsection{Beech-sugar maple relationships}

A positive relationship was found between beech and sugar maple densities with all five models (Table 7). In addition, the slopes of the models were similar, ranging from $0.014 \pm 0.007$ for equation iii to $0.025 \pm 0.008$ for equation $v$. The values of the slopes suggest a small increase in sugar maple densities with increasing beech densities. For instance, the model investigating the relationship between $\mathrm{h} 1$ sugar maple and total beech shows that when beech density was two stems $\mathrm{m}^{-2}$, sugar maple density was 2.2 stems $\mathrm{m}^{-2}$, but when beech density was 15 stems $\mathrm{m}^{-2}$, sugar maple density only increased to 2.9 stems $\mathrm{m}^{-2}$. The standard deviation of the site random effect showed that there was greater variability among sites when h1 sugar maple was the dependent variable (1.068 to $1.075)$ in the model than when $\mathrm{h} 2+\mathrm{h} 3$ sugar maple was the dependent variable (0.354 to 0.360$)$.

\section{Discussion}

4.1 Beech and sugar maple spatial patterns

We initially observed an even cover of beech regeneration across the post-harvest study areas, which led to the hypothesis that beech spatial patterns were random. We rejected this

Table 3 Total stem density (thousand stems per ha) of the five most abundant hardwood species by height class for each of the three sites

\begin{tabular}{|c|c|c|c|c|c|c|c|c|c|}
\hline \multirow[b]{2}{*}{ Species } & \multicolumn{3}{|l|}{ Site 1} & \multicolumn{3}{|l|}{ Site 2} & \multicolumn{3}{|l|}{ Site 3} \\
\hline & h1 & $\mathrm{h} 2$ & h3 & h1 & $\mathrm{h} 2$ & h3 & h1 & $\mathrm{h} 2$ & h3 \\
\hline American beech & 0.94 & 3.19 & 12.72 & 10.75 & 22.29 & 9.50 & 3.82 & 3.66 & 2.45 \\
\hline Sugar maple & 96.82 & 29.77 & 1.09 & 6.70 & 3.63 & 2.53 & 41.18 & 15.61 & 2.64 \\
\hline Striped maple & 5.87 & 4.74 & 2.74 & 0.78 & 0.95 & 1.94 & 12.48 & 10.78 & 8.12 \\
\hline Red maple & 18.54 & 1.41 & 1.13 & 0.54 & 0.50 & 0.36 & 2.79 & 2.53 & 1.28 \\
\hline Yellow birch & 5.56 & 4.03 & 4.44 & 0.47 & 1.18 & 0.45 & 15.29 & 14.37 & 10.83 \\
\hline
\end{tabular}

Height classes were h1, 6 to $30 \mathrm{~cm}$; h2, 31 to $90 \mathrm{~cm}$; and h3, $91 \mathrm{~cm}$ to $<4 \mathrm{~cm} \mathrm{dbh}$ 
Table 4 Average age (standard deviation) and proportion of American beech root suckers by height class for each of the three sites

\begin{tabular}{|c|c|c|c|c|c|}
\hline & Species & Height class & Site 1 & Site 2 & Site 3 \\
\hline \multirow[t]{6}{*}{ Age (years) } & Sugar maple & h1 & $2.5(0.7)$ & $4.2(1.5)$ & $2.0(0.1)$ \\
\hline & & $\mathrm{h} 2$ & $5.2(2.4)$ & $5.4(1.7)$ & $3.6(1.0)$ \\
\hline & & h3 & $7.0(4.0)$ & $8.5(2.5)$ & $6.2(2.6)$ \\
\hline & Beech & h1 & - & $3.7(0.6)$ & $3.0(0.5)$ \\
\hline & & h2 & $5.2(1.5)$ & $5.3(1.2)$ & $5.1(1.3)$ \\
\hline & & $\mathrm{h} 3$ & $7.4(1.7)$ & $9.9(3.1)$ & $7.7(4.3)$ \\
\hline Beech root-sucker proportion (\%) & & & 11.2 & 6.9 & 21.2 \\
\hline
\end{tabular}

Height classes were h1, 6 to $30 \mathrm{~cm}$; h2, 31 to $90 \mathrm{~cm}$; and h3, $91 \mathrm{~cm}$ to $<4 \mathrm{~cm} \mathrm{dbh}$

hypothesis because autocorrelation was detected for all three height classes, indicating clumped spatial patterns. The clumped spatial patterning of beech regeneration was influenced by the pre-harvest understory conditions, since most individuals were in $\mathrm{h} 2$ and $\mathrm{h} 3$ height classes that were between 5 and 10 years old, and the harvests occurred 5 to 7 years before measurement. Pre-harvest basal areas ranged from 30 to $34 \mathrm{~m}^{2} \mathrm{ha}^{-1}$, where beech occupied between $16 \%$ (S3) and $88 \%$ (S2). Since the forests were in the "aftermath stage" of beech bark disease, many of the beech overstory trees and crowns were declining, which would have allowed light to penetrate to the understory and stimulate beech regeneration

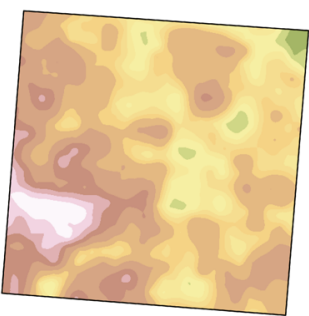

a) sugar maple h1

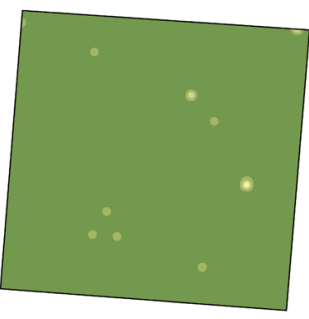

e) beech h1

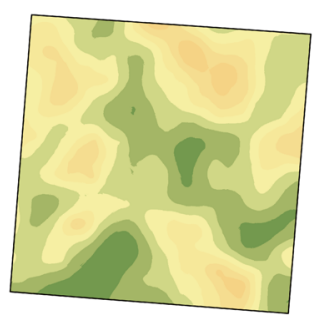

b) sugar maple h2

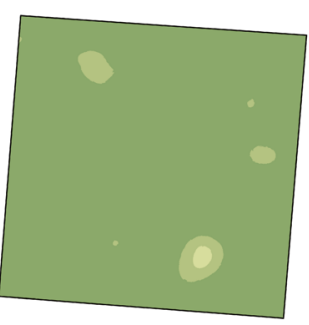

f) beech h2

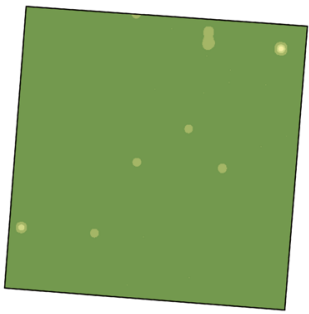

c) sugar maple h3

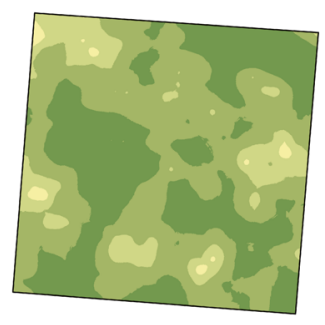

g) beech h3

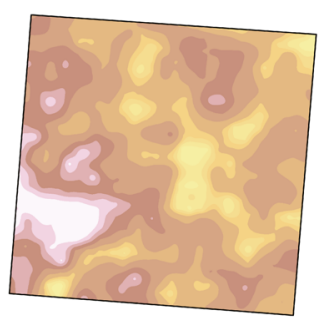

d) sugar maple total

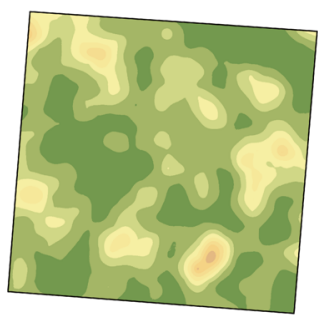

h) beech total<smiles></smiles>

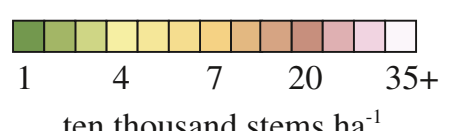

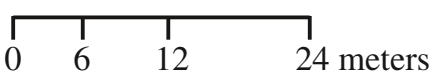

ten thousand stems ha ${ }^{-1}$

Fig. 1 Kriged surfaces of sugar maple (a-d) and American beech (e-h) stem densities (stems $\mathrm{m}^{-2}$ ) at Site 1 by height class and for total stem density. Lighter shades indicate greater stem densities, ranging from 0 to
30 stems $\mathrm{m}^{-2}$. Height classes were h1, 6 to $30 \mathrm{~cm}$; h2, 31 to $90 \mathrm{~cm}$; and $\mathrm{h} 3,91 \mathrm{~cm}$ to $<4 \mathrm{~cm}$ dbh 


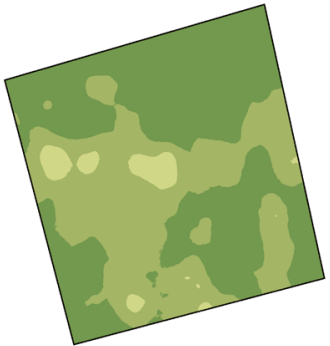

a) sugar maple h1

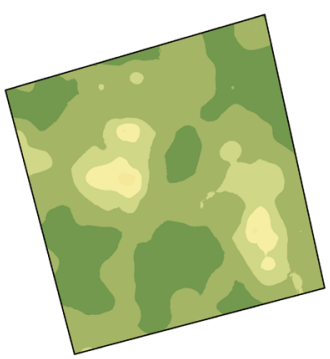

e) beech h1

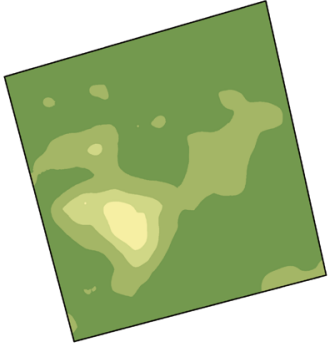

b) sugar maple h2

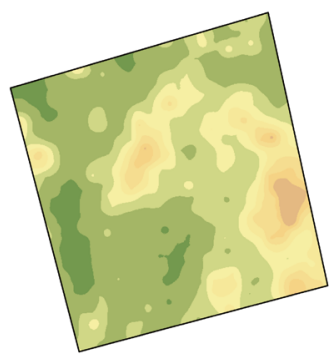

f) beech h2

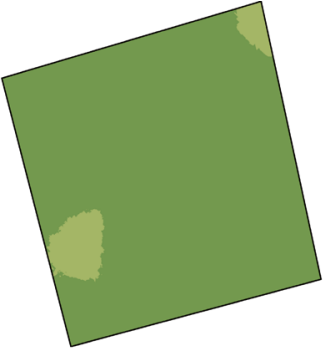

c) sugar maple h3

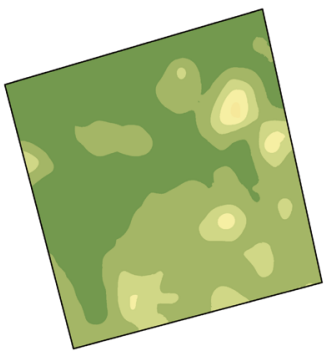

g) beech h3

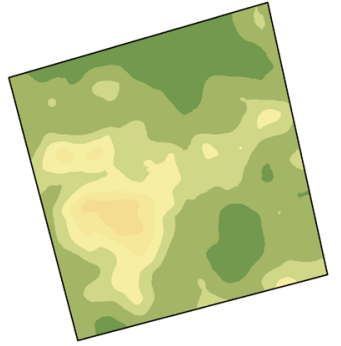

d) sugar maple total

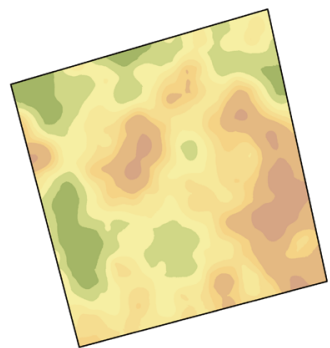

h) beech total<smiles>NC1NC(F)CS1</smiles>

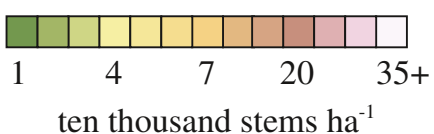

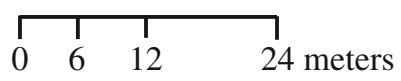

30 stems $\mathrm{m}^{-2}$. Height classes were h1, 6 to $30 \mathrm{~cm}$; h2, 31 to $90 \mathrm{~cm}$; and $\mathrm{h} 3,91 \mathrm{~cm}$ to $<4 \mathrm{~cm}$ dbh

available microsites (Caspersen and Saprunoff 2005; Godman et al. 1990). The residual sugar maple overstory basal area was between $3.0 \mathrm{~m}^{2} \mathrm{ha}^{-1}$ (S2) and $4.3 \mathrm{~m}^{2} \mathrm{ha}^{-1}$ (S1), which would have been sufficient to provide seeds for regeneration since $\mathrm{h} 1$ sugar maple was between 2 and 4 years old. Self-thinning of the high seedling densities within the patches is inevitable, but we expect sugar maple to competitively exclude other species within these clumps, ensuring sugar maple will be present through development in the areas. Although factors such as mammalian browsing and acidic soils may negatively influence sugar maple regeneration (Didier and Porter 2003; Long et al. 1997), the high seedling densities and lack of observable browse (personal observation) should not affect the viability of the species.

Our hypothesis that taller $(\mathrm{h} 2+\mathrm{h} 3)$ sugar maple spatial patterns were random was rejected because significant autocorrelation was detected, with average patch sizes of 8.40 and $8.62 \mathrm{~m}$ for $\mathrm{h} 2$ and $\mathrm{h} 3$, respectively. We suspected that the taller sugar maple would establish as scattered advance regeneration individuals among the more competitive beech prior to overstory disturbance since beech is better adapted to very low-light conditions (Canham 1988). The results suggest that the pre-harvest beechfree microsites were suitable for sugar maple 


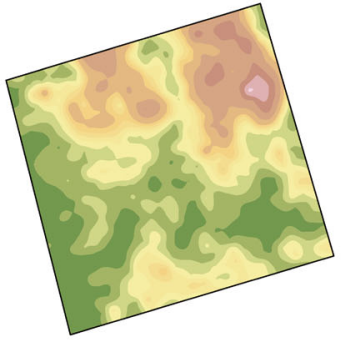

a) sugar maple h1

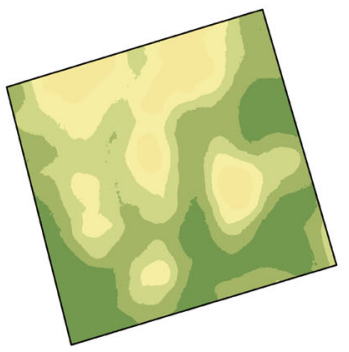

e) beech $h 1$

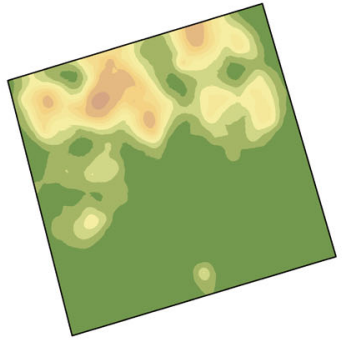

b) sugar maple h2

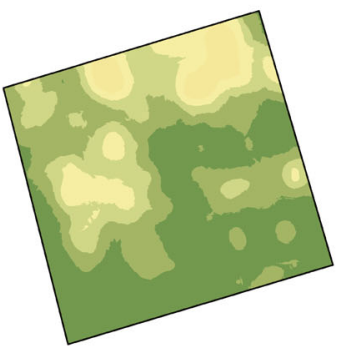

f) beech h2

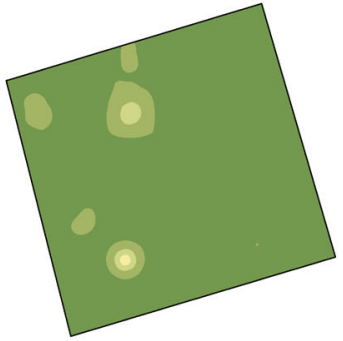

c) sugar maple h3

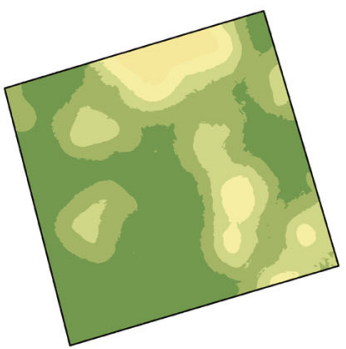

g) beech h3

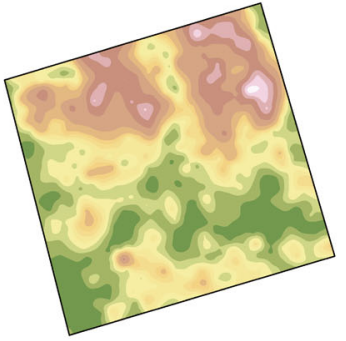

d) sugar maple total

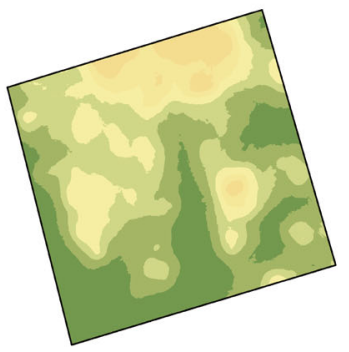

h) beech total<smiles>FC1NC2NC1S2</smiles>

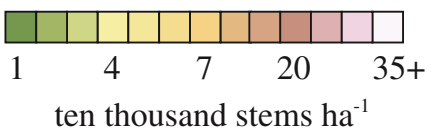

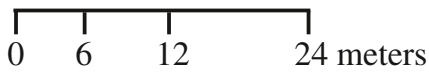

Fig. 3 Kriged surfaces of sugar maple (a-d) and American beech $(\mathbf{e}-\mathbf{h})$ stem densities (stems $\mathrm{m}^{-2}$ ) at Site 3 by height class and for total stem density. Lighter shades indicate greater stem densities, ranging from 0 to

30 stems $\mathrm{m}^{-2}$. Height classes were h1, 6 to $30 \mathrm{~cm}$; h2, 31 to $90 \mathrm{~cm}$; and $\mathrm{h} 3,91 \mathrm{~cm}$ to $<4 \mathrm{~cm}$ dbh

establishment, maybe because of areas with greater light penetration, such as through the declining beech canopy.

\subsection{Beech and sugar maple coexistence}

Overlapping patches of beech and sugar maple (Figs. 1, 2, and 3 ) and positive correlations found with regression (Table 7) suggest both species were growing on the same microsites. Therefore, we rejected the hypothesis of negatively related spatial patterns. The two species often coexist within northern hardwood stands (Poulson and Platt 1996), because of

Table 5 Means and coefficients of variation (CV) of autocorrelation ranges by site, averaged among height classes

\begin{tabular}{|c|c|c|c|}
\hline Species & Site 1 & Site 2 & Site 3 \\
\hline American beech & $\begin{array}{l}2.76 \mathrm{a} \\
(0.92)\end{array}$ & $\begin{array}{l}9.51 \mathrm{~b} \\
(0.35)\end{array}$ & $\begin{array}{l}6.28 \mathrm{ab} \\
(0.28)\end{array}$ \\
\hline Sugar maple & $\begin{array}{l}8.38 \mathrm{a} \\
(0.35)\end{array}$ & $\begin{array}{l}7.51 \mathrm{a} \\
(0.12)\end{array}$ & $\begin{array}{l}11.79 \mathrm{a} \\
(0.02)\end{array}$ \\
\hline
\end{tabular}

$\mathrm{CVs}$ are shown in parentheses. For each row, the same letters $(\mathrm{a}, \mathrm{b})$ indicate mean values that were not significantly different between sites at $p \leq 0.05$, based on one-way ANOVA results of range of autocorrelation as the dependent variable and site as the independent variable differences in growth and survival in relation to canopy openness (Forcier 1975; Poulson and Platt 1996) and soil texture and chemical content (Arii and Lechowicz 2002). We did not expect microsite coexistence because of niche partitioning (sensu Grubb 1977) where beech would capture available space prior to overstory disturbance, while sugar maple would occur primarily in beech-free patches. Niche partitioning is also a mechanism proposed for maintaining diversity in tropical rainforests, where non-random regeneration spatial patterns have been attributed to sub-stand microtopographic gradients (Clark et al. 1998) and species differences in dispersal

Table 6 Means and coefficients of variation (CV) of autocorrelation ranges by height (height 1,6 to $30 \mathrm{~cm}$; height 2, 31 to $90 \mathrm{~cm}$; and height $3,91 \mathrm{~cm}$ to $<4 \mathrm{~cm} \mathrm{dbh}$ ), averaged among sites

\begin{tabular}{llll}
\hline Species & Height 1 & Height 2 & Height 3 \\
\hline American beech & $3.52 \mathrm{a}$ & $6.95 \mathrm{a}$ & $8.08 \mathrm{a}$ \\
& $(0.90)$ & $(0.48)$ & $(0.51)$ \\
Sugar maple & $10.67 \mathrm{a}$ & $8.40 \mathrm{a}$ & $8.62 \mathrm{a}$ \\
& $(0.18)$ & $(0.37)$ & $(0.30)$ \\
\hline
\end{tabular}

CVs are shown in parentheses. For each row, the same letters (a) indicate mean values that were not significantly different between height classes at $p \leq 0.05$, based on one-way ANOVA results of range of autocorrelation as the dependent variable and height class as the independent variable 
Table 7 Linear mixed-effects intercept and slope parameter estimates with standard errors in parentheses and associated $p$ values

\begin{tabular}{|c|c|c|c|c|c|c|c|c|c|}
\hline Dependent variable & Independent variable & Intercept (SE) & $p$ value & Slope (SE) & $p$ value & Site SD & Range (m) & Nugget (m) & $R^{2}$ \\
\hline Sugar maple h1 & Beech total & $1.455(0.686)$ & 0.034 & $0.016(0.008)$ & 0.033 & 1.075 & 15.382 & 0.163 & 0.405 \\
\hline Sugar maple h1 & Beech h2+h3 & $1.464(0.682)$ & 0.032 & $0.016(0.009)$ & 0.078 & 1.068 & 15.362 & 0.162 & 0.403 \\
\hline Sugar maple h2+h3 & Beech total & $0.808(0.281)$ & 0.004 & $0.014(0.007)$ & 0.035 & 0.360 & 13.134 & 0.241 & 0.126 \\
\hline Sugar maple h2+h3 & Beech h2+h3 & $0.813(0.279)$ & 0.004 & $0.015(0.008)$ & 0.052 & 0.354 & 13.136 & 0.241 & 0.125 \\
\hline Sugar maple total & Beech total & $1.836(0.742)$ & 0.013 & $0.025(0.008)$ & 0.002 & 1.170 & 13.874 & 0.136 & 0.404 \\
\hline
\end{tabular}

Also shown is the standard deviation of the site random effect, range, and nugget parameters of the spherical variograms included in the models to account for the residual correlation. Five models were fit with sugar maple height class 1 (h1), height class 2 (h2), height class 3 (h3), and total density as the dependent variables, and beech height classes h2 and h3 and total density as the independent variables

mechanisms. For instance, coexistence of some tropical tree species in forests with heterogeneous overstory conditions is attributed to niche differentiation where high rates of growth and survival vary by light availability (Kobe 1999). Although not nearly as diverse, five hardwood species (beech, sugar maple, red maple, striped maple, and yellow birch) were common across our sites. All these species have different regeneration mechanisms and microsite requirements. Stochastic seed fall patterns, heterogeneous growing space before and after harvest, and inherent species-specific traits (e.g., shade tolerance) interacted to produce coexistent understories.

Overlapping patches and positive correlations between $\mathrm{h} 1$ sugar maple and total beech is particularly interesting, as it demonstrates understory stratification, with beech overtopping sugar maple. Similar patterns have been found in Quebec, Canada following catastrophic overstory disturbance (Beaudet et al. 2007). Pre-harvest understory stratification was unlikely due to low-light availability since radiation decreases exponentially with increasing leaf area (Vose et al. 1995). This would have excluded almost all light beneath advance regeneration beech. Following overstory disturbance, a sufficient amount of light must have penetrated through the beech strata to allow sugar maple establishment. Beech already had a height advantage, so it is unlikely that the sugar maple established beneath will displace the beech without some form of understory treatment.

The mosaic of overlapping and non-overlapping patches of beech and sugar maple across the areas will influence future development. Species differences in regeneration strategies, including seed dispersal and response to canopy gaps, will ensure that both species will be present in the future. As the beech-dominated patches mature and succumb to beech bark disease, a new patchy advance regeneration understory may form, resulting in perpetual self-replacement. These ecological patterns pose major management concerns since such patterns would reduce the economic viability of these industrially managed forests. The coexistent post-harvest patches of beech and sugar maple suggest selective techniques that remove beech while releasing overtopped sugar maple seedlings could shift regeneration dominance to sugar maple and minimize beech self-replacement (Nelson and Wagner 2011). Removing beech patches would also create suitable microsites for the establishment of other light-seeded species, such as red maple and yellow birch.

Acknowledgments CFRU members Huber Resources, Prentiss \& Carlisle, and Katahdin Forest Management provided study sites for this project. We would also like to thank our field assistants Erica Kaufmann, Kyle Gay, and Alexandria Small.

Funding Financial support for this project was provided by the Cooperative Forestry Research Unit (CFRU) and the Henry W. Saunders Chair at the University of Maine.

\section{References}

Arii K, Lechowicz MJ (2002) The influence of overstory trees and abiotic factors on the sapling community in an old-growth Fagus-Acer forest. Ecoscience 9:386-396

Beatty SW (1984) Influence of microtopography and canopy species on spatial patterns of forest understory plants. Ecology 65:1406-1419. doi: $10.2307 / 1939121$

Beaudet M, Brisson J, Gravel D, Messier C (2007) Effect of a major canopy disturbance on the coexistence of Acer saccharum and Fagus grandifolia in the understorey of an old-growth forest. J Ecol 95:458-467. doi:10.1111/j.1365-2745.2007.01219.x

Bivand R (2013) spdep: spatial dependence: weighting schemes, statistics and models. Version 0.5-57

Bohn K, Nyland R (2003) Forecasting development of understory American beech after partial cutting in uneven-aged northern hardwood stands. For Ecol Manag 180:453-461. doi:10.1016/S03781127(02)00614-X

Canham CD (1988) Growth and canopy architecture of shade-tolerant trees: response to canopy gaps. Ecology 69:786-795. doi:10.2307/ 1941027

Canham CD (1990) Suppression and release during canopy recruitment in Fagus grandifolia. B Torrey Bot Club 117:1-7. doi:10.2307/ 2997123

Caspersen JP, Saprunoff M (2005) Seedling recruitment in a northern temperate forest: the relative importance of supply and establishment limitation. Can J For Res 35:978-989. doi:10.1139/x05-024

Clark DB, Clark DA, Read JM (1998) Edaphic variation and the mesoscale distribution of tree species in a neotropical rainforest. J Ecol $86: 101-112$ 
Didier KA, Porter WF (2003) Relating spatial patterns of sugar maple reproductive success and relative deer density in northern New York State. For Ecol Manag 181:253-266. doi:10.1016/S0378-1127(03) 00137-3

Forcier LK (1975) Reproductive strategies and the co-occurrence of climax tree species. Science 189:808-810. doi:10.1126/science. 189.4205.808

Godman RM, Yawney HW, Tubbs CH (1990) Sugar maple (Acer saccharum Marsh.). In: Burns RM, Honkala BH (eds) Silvics of North America. USDA Handbook 654, vol 2. pp 78-91

Grubb PJ (1977) The maintenance of species-richness in plant communities: the importance of the regeneration niche. Biol Rev 52:107145. doi:10.1111/j.1469-185X.1977.tb01347.x

Houle G (1994) Spatiotemporal patterns in the components of regeneration of four sympatric tree species-Acer rubrum, Acer saccharum, Betula alleghaniensis, and Fagus grandifolia. J Ecol 82:39-53. doi: $10.2307 / 2261384$

Houston DR (1994) Major new tree disease epidemics: beech bark disease. Ann Rev Phytopathol 32:75-87. doi:10.1146/annurev. phyto.32.1.75

Houston DR (2001) Effect of harvesting regime on beech root sprouts and seedlings in a north-central Maine forest long affected by beech bark disease. USDA, Forest Service, Northeastern Research Station, Newtown Square, PA

Hughes JW, Fahey TJ (1988) Seed dispersal and colonization in a disturbed northern hardwood forest. B Torrey Bot Club 115:8999. doi:10.2307/2996139

Jones RH, Raynal DJ (1986) Spatial distribution and development of root sprouts in Fagus grandifolia (Fagaceae). Am J Bot 73:1723-1731. doi: $10.2307 / 2444238$

Juice SM, Fahey TJ, Siccama TG, Driscoll CT, Denny EG, Eagar C, Cleavitt NL, Minocha R, Richardson AD (2006) Response of sugar maple to calcium addition to northern hardwood forest. Ecology 87 : 1267-1280. doi: $10.1890 / 0012-9658(2006) 87 \%$ 5B1267:ROSMTC\%5D2.0.CO;2

Kobe RC (1999) Light gradient partitioning among tropical tree species through differential seedling mortality and growth. Ecology 80:187201. doi: $10.2307 / 176989$

Kozlowski TT (2002) Physiological ecology of natural regeneration of harvested and disturbed forest stands: implications for forest management. For Ecol Manag 158:195-221. doi:10.1016/S03781127(00)00712-X

Legendre P, Fortin MJ (1989) Spatial pattern and ecological analysis. Plant Ecol 80:107-138. doi:10.1007/BF00048036
Long RP, Horsley SB, Lilja PR (1997) Impact of forest liming on growth and crown vigor of sugar maple and associated hardwoods. Can J For Res 27:1560-1573. doi:10.1139/x97-074

Messaoud Y, Houle G (2006) Spatial patterns of tree seedling establishment and their relationship to environmental variables in a coldtemperate deciduous forest of eastern North America. Plant Ecol 185:319-331. doi:10.1007/s11258-006-9106-7

Morin RS, Liebhold AM, Tobin PC, Gottschalk KW, Luzader E (2007) Spread of beech bark disease in the eastern United States and its relationship to regional forest composition. Can J For Res 37:726736. doi:10.1139/X06-281

Nagel TA, Svoboda M, Rugani T, Diaci J (2010) Gap regeneration and replacement patterns in an old-growth Fagus-Abies forest of Bosnia-Herzegovina. Plant Ecol 208:307-318

Nelson AS, Wagner RG (2011) Improving the composition of beechdominated northern hardwood understories in northern Maine. North J Appl For 28:186-193

Pinheiro J, Bates D, DebRoy S, Sarkar D, R-core, EISPACK (2013) nlme: linear and nonlinear mixed effects models, version 3.1-109. Version 3.1-100

Poulson TL, Platt WJ (1996) Replacement patterns of beech and sugar maple in Warren Woods, Michigan. Ecology 77:1234-1253. doi:10. $2307 / 2265592$

R Core Team (2013) R: A language and environment for statistical computing. R Foundation for Statistical Computing, Vienna, Austria. URL http://www.R-project.org/

Ribbens E, Silander JA Jr, Pacala SW (1994) Seedling recruitment in forests: calibrating models to predict patterns of tree seedling dispersion. Ecology 75:1794-1806. doi:10.2307/1939638

Tubbs CH, Houston DR (1990) American beech (Fagus grandifolia Ehrh.). In: Burns RM, Honkala BH (eds) Silvics of North America, vol 2, vol 654, USDA Forest Service Handbook., pp 325-332

Vose JM, Clinton BD, Sullivan NH, Bolstad PV (1995) Vertical leaf area distribution, light transmittance, and application of the BeerLambert law in four mature hardwood stands in the southern Appalachians. Can J For Res 25:1036-1043. doi:10.1139/x95-113

Ward, RT (1961) Some aspects of regeneration habits of the American beech. Ecology 42:828-832. doi:10.2307/1933517

Ward JS, Parker GR (1989) Spatial dispersion of woody regeneration in an old-growth forest. Ecology 70:1279-1285. doi:10.2307/1938187

Wharton EH (1984) Predicting diameter at breast height from stump diameters for northeastern tree species. Newtown Square, PA: USDA, Forest Service. NE-322 